\title{
Evaluation of Aircraft Excursion Risk at Bandaranaike International Airport
}

\author{
S.D.B. Galagedera, H.R. Pasindu and V. Adikarivattage
}

\begin{abstract}
Flight safety is one of the key priorities in the air transport industry. Considering historical aircraft accidents, majority of the aircraft accident occurred at airports. Among the airport related aircraft accidents, a higher percentage of accidents have taken place during the landing operations. Runway excursions such as overruns and veer-offs are the typical runway related aircraft accidents that frequently occur during aircraft landings. Thus, this paper focuses on aircraft excursion risk at the Bandaranaike International Airport (BIA) where the majority of the international flight movements are currently taking place in Sri Lanka.

This paper considers different operational conditions that probably exist at BIA, and accordingly associated excursion risks are estimated. Aircraft airfield design elements such as the runway length, safety areas and the corresponding critical aircraft for the BIA are used for the estimation. Potential overrun and veer-off risks at aircraft landings are mainly focused. The methodology follows a quantitative approach which consists of event probability, location probability and consequent severity estimation steps. Among the potential weather factors, the conditions at which tailwind over 12 knots $(6.17 \mathrm{~m} / \mathrm{s})$, reduced visibility and rain are the worst contributory factors for the greatest overrun risk. The paper highlights that the airfield design elements can compensate excursion risks that generate due to various spikes of the operational conditions.
\end{abstract}

Keywords: Excursion, Overrun, Veer-off, Airfield

\section{Introduction}

\subsection{Aircraft Accidents}

Worldwide aircraft accidents are considered, total aircraft accident rate in 2019 was 1.13 per million flights [1]. The majority of the aircraft accidents take place at airports or airport vicinity areas [2]. A higher proportion of aircraft accidents have occurred during landing and take off phases. Aircraft excursions are the leading accident type during landings and take offs. Thus, airport runways incur associated aircraft excursion risk.

Runway excursion is defined as an inappropriate exit of an aircraft from the runway. That is, an aircraft is unable to stop before it reaches the end of the runway or exceeds the lateral limits. Such stopping locations longitudinally away from the runway ends, are defined as overruns, and laterally away from the runway edges are defined as veer-offs.

Runway excursions are divided into five main categories such as landing overruns (LDOR), landing undershoots (LDUS), landing veer-offs (LDVO), take-off overruns (TOOR) and take-off veer-offs (TOVO) [2]. Among the historical worldwide runway excursions, the landing overruns are identified as the most frequent type of excursion event [3]. Further, landing veer-offs are also comparatively 4 times higher than the veer-offs during take-off operations [4]. Aircraft accident statistics indicate that about 80 percent of the veered-off aircraft have stopped within $52.5 \mathrm{~m}$ from the runway edge [4].

It is observed a consistent annual air passenger growth about $6 \%$ is observed during the previous decade and it is forecasted about 40 billion annual air passenger travels in 2040 [5]. Increasing passenger volumes are considered, airport runways need to facilitate for increasing number of aircraft movements and new larger aircrafts as well. Accordingly, airport runways become more congested and associated excursion risk will also be worse.

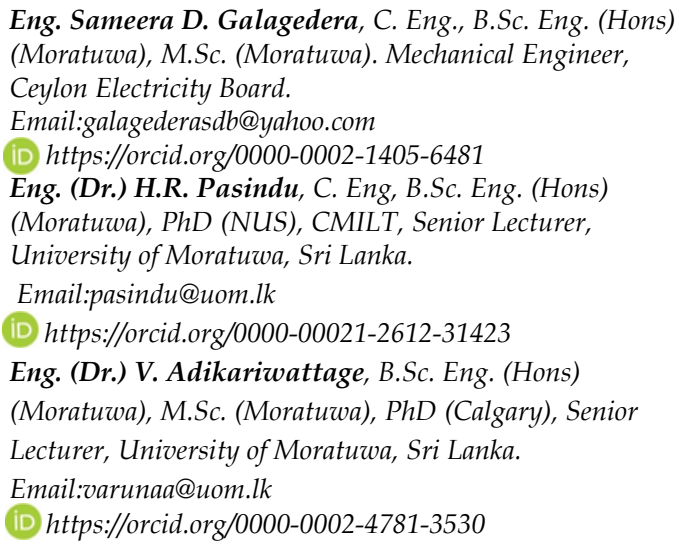


Considering the associated aircraft risk at existing airport runways, it is important to assess associated risks in order to minimize them. Using the same approach, risk-based designs for future runways are also worthwhile with regard to air transport safety.

Bandaranaike International Airport (BIA) is the main international airport still serving for $99 \%$ of the international flight movements in Sri Lanka. It is approximately 72000 annual flight movements [6]. As per the Civil Aviation Authority of Sri Lanka [7], there were no major excursion events recorded in BIA other than a tail strike at a hard landing in 2013. However, considering the future operations at BIA, this paper focuses on the potential excursion risk of landing at Bandaranaike International airport.

\section{Literature}

\subsection{What is Risk?}

Risk is defined as an impact of a hazard to a person, asset or an operation. It is a function of the likelihood of an event and the corresponding consequences of the same event (Equation 1). Accordingly, a higher the likelihood of an event, or higher the severity (consequences), the associated risk will be higher. For excursion risk estimation, likelihood of an event is further divided into event frequency estimation and the respective location probability estimation (Equation 2).

Risk $(R)=$ Likelihood of event $(P) \times$ Severity $(D)$

$P=P 1 \times P 2$

where,

$P 1=$ Likelihood for occurrence of an event

$P 2=$ Probability that an aircraft passes a certain distance from the runway due to an event

\subsection{Probability Model (P1)}

There is a large number of studies conducted on aircraft excursion risk analysis and they have followed a quantitative approach. With the initial one dimensional probability models of Eddowes (2001) and Kirkland (2001), Wong et al. [8] developed a probability model including aircraft and weather related multiple risk factors. their multivariate probability model was modified by Hall et al. [2] including few more risk factors under the Airport Cooperative Research Program (ACRP) for Analysis of Aircraft Overruns and Undershoots for Runway Safety Areas. In 2011, Ayres et al. developed a similar model for veer-off probability analysis [9]. This included a risk factor called runway criticality factor. This was the first time a runway design element (runway length) was taken into account for runway excursion event probability modelling. Trucco et al. (2013) developed a risk map for airport safety areas [10]. In this approach, the expected kinetic energy of the overrun aircraft at any given point was used as the event severity. Considering the latest accident data and aircraft types, Ayres et al. [9] further modified veer-off probability model for landings in 2014 under the ACRP study "Development of a Runway veer-off location distribution risk assessment and reporting template" [4]. Similarly, Shirazi et al. [11] modified landing overrun probability model in the tool development for "Runway Protection Zones (PPZ) Risk Assessment". In the study conducted by Moretti et al. (2017), wind distribution was related with the veer-off probability estimation [12].

Shirazi's landing overrun probability model is used in this analysis as shown in Equation 3. Further, the probability model developed by Ayres et al. (2014) is used for landing veer-off probability estimation.

$P($ landing overrun $)=\frac{1}{1+e^{-z}}$

where,

$Z=$ regression coefficients $X$ independent

variables

For landing overrun probability model, $Z=-11.96-3.32($ Hub $)+1.71$ (Foreign $O / D)-$ 1.18 (Aircraft class A) + 2.25 (Piston) -1.22 (Prop) +1.6 (Fog) +1.50 (Icing) +1.61 (Night) +0.76 $($ Rain $)+1.57$ (Snow) -1.23 (Electric Storm) -0.86 (Temperature greater than $25 \mathrm{C}$ ) +0.94 (Tailwind between 5 and $12 \mathrm{kts}$ ) +3.22 (Tailwind greater than $12 \mathrm{kts})+1.60$ (Visibility less than $2 \mathrm{SM})+0.98$ (Visibility between 2 and 4 SM) - 1.11 (Crosswind between 2 and $5 \mathrm{kts}$ ) -0.47 (Crosswind between 5 and $12 \mathrm{kts})+5.82($ Log Criticality fct $)$

Input variables for the overrun model are defined in Table 1.

Table 1 - Input Variables - Overrun Model

\begin{tabular}{|l|l|}
\hline \multicolumn{1}{|c|}{ Variable } & \multicolumn{1}{c|}{ Definition } \\
\hline Hub & $\begin{array}{l}\text { An airport where } \\
\text { connecting flight } \\
\text { operations take place }\end{array}$ \\
\hline $\begin{array}{l}\text { Foreign Origin- } \\
\text { Destination }\end{array}$ & $\begin{array}{l}\text { An airport where } \\
\text { international flight } \\
\text { operations take place }\end{array}$ \\
\hline Aircraft class A & $\begin{array}{l}\text { Maximum take-off } \\
\text { weight 12.5lbs or less }\end{array}$ \\
\hline Piston & Piston engine aircraft \\
\hline
\end{tabular}




\begin{tabular}{|l|l|}
\hline Propeller & Propeller engine aircraft \\
\hline Fog & Presence of fog \\
\hline Icing & $\begin{array}{l}\text { Presence of ice on the } \\
\text { runway }\end{array}$ \\
\hline Night & Presence of rain \\
\hline Rain & $\begin{array}{l}\text { Presence of snow on the } \\
\text { runway }\end{array}$ \\
\hline Snow & $\begin{array}{l}\text { Presence of electric } \\
\text { storms }\end{array}$ \\
\hline Electric storm \\
\hline $\begin{array}{l}\text { Temperature } \\
\text { greater than } 25^{\circ} \mathrm{C}\end{array}$ & $\begin{array}{l}\text { Ambient temperature } \\
\text { above } 25^{\circ} \mathrm{C}\end{array}$ \\
\hline $\begin{array}{l}\text { Tailwind } \\
\text { between } 5 \mathrm{kts} \\
\text { and } 12 \mathrm{kts}\end{array}$ & $\begin{array}{l}\text { Presence of tailwind } \\
\text { between } 5 \text { knots and } 12 \\
\text { knots }\end{array}$ \\
\hline $\begin{array}{l}\text { Tailwind greater } \\
\text { than } 12 \mathrm{kts}\end{array}$ & $\begin{array}{l}\text { Presence of tailwind } \\
\text { greater than } 12 \text { knots }\end{array}$ \\
\hline $\begin{array}{l}\text { Visibility less } \\
\text { than 2 SM }\end{array}$ & $\begin{array}{l}\text { When visibility less than } \\
\text { 2 Salute miles }\end{array}$ \\
\hline $\begin{array}{l}\text { Visibility } \\
\text { between 2-4 SM }\end{array}$ & $\begin{array}{l}\text { When visibility between } \\
\text { 2 and } 4 \text { Salute miles }\end{array}$ \\
\hline $\begin{array}{l}\text { Crosswind } \\
\text { between 2-5 kts }\end{array}$ & $\begin{array}{l}\text { Presence of crosswind } \\
\text { between } 2 \text { and } 5 \text { knots }\end{array}$ \\
\hline $\begin{array}{l}\text { Crosswind } \\
\text { between 5-12 kts }\end{array}$ & $\begin{array}{l}\text { Presence of crosswind } \\
\text { between } 5 \text { and } 12 \text { knots }\end{array}$ \\
\hline $\begin{array}{l}\text { Log criticality } \\
\text { factor }\end{array}$ & Defined in Equation 4 \\
\hline
\end{tabular}

For landing veer-off probability,

$Z=-13.088+1.682$ (User Class G) -0.770 (Aircraft Class A/B) - 0.252 (Aircraft Class D/E/F) +2.143 (Visibility less than 2SM) + 0.653 (Crosswind between 5-12kt) - 0.091 (Crosswind between $2-5 k t)+2.192$ (Crosswind greater than $>12 k t)+0.066$ (Tailwind between 5-12kt) +0.98 (Tailwind greater than $12 k t)+0.558$ (Temperature less than 5C) - 0.453 (Temperature between 5-15C) +0.29 (Temperature greater than 25C) +2.67 (Icing conditions) -0.126 (Rain) +0.548 (Snow) 0.103 (Frozen Precipitation) -0.036 (Guts) +1.74 (Fog) - 2.517 (Turboprop) - 0.334 (Foreign OD) + 4.318 (Log Criticality fct) - 1.36 (Night condition)

Input variables for the veer-off model are defined in Table 1.

Table 2 - Input variables - Veer-off model

\begin{tabular}{|l|l|}
\hline \multicolumn{1}{|c|}{ Variable } & \multicolumn{1}{c|}{ Definition } \\
\hline User Class G & $\begin{array}{l}\text { General aviation flight } \\
\text { maximum take-off } \\
\text { weight less than 6k lb }\end{array}$ \\
\hline $\begin{array}{l}\text { Aircraft Class } \\
\text { A/B }\end{array}$ & $\begin{array}{l}\text { Aircraft maximum take- } \\
\text { off weight 255,000 lb or } \\
\text { above }\end{array}$ \\
\hline $\begin{array}{l}\text { Aircraft Class } \\
\text { D/E/F }\end{array}$ & $\begin{array}{l}\text { Maximum take-off } \\
\text { weight } \\
\text { Class D - 41k - 255k lb, }\end{array}$ \\
\hline
\end{tabular}

\begin{tabular}{|c|c|}
\hline & $\begin{array}{l}\text { Class E - } 12.5 \mathrm{k}-41 \mathrm{k} \mathrm{lb} \\
\text { Class F - } 12.5 \mathrm{k} \text { lb or less }\end{array}$ \\
\hline $\begin{array}{l}\text { Visibility less } \\
\text { than } 2 \text { SM }\end{array}$ & $\begin{array}{l}\text { When visibility less than } \\
2 \text { Salute miles }\end{array}$ \\
\hline $\begin{array}{l}\text { Crosswind } 5-12 \\
\text { kts }\end{array}$ & $\begin{array}{l}\text { Presence of crosswind } \\
\text { between } 5 \text { knots - } 12 \\
\text { knots }\end{array}$ \\
\hline $\begin{array}{l}\text { Crosswind } 2-5 \\
\text { kts }\end{array}$ & $\begin{array}{l}\text { Presence of crosswind } \\
\text { between } 2-12 \text { knots }\end{array}$ \\
\hline $\begin{array}{l}\text { Crosswind more } \\
\text { than } 12 \text { kts }\end{array}$ & $\begin{array}{l}\text { Presence of crosswind } \\
\text { greater than } 12 \text { knots }\end{array}$ \\
\hline $\begin{array}{l}\text { Tailwind } \\
\text { between 5-12 kts }\end{array}$ & $\begin{array}{l}\text { Presence of tailwind } \\
\text { between } 5-12 \text { knots }\end{array}$ \\
\hline $\begin{array}{l}\text { Tailwind greater } \\
\text { than } 12 \mathrm{kts}\end{array}$ & $\begin{array}{l}\text { Presence of tailwinds } \\
\text { greater than } 12 \text { knots }\end{array}$ \\
\hline $\begin{array}{l}\text { Temp less than } 5 \\
\text { C }\end{array}$ & $\begin{array}{l}\text { Ambient temperature } \\
\text { below } 25^{\circ} \mathrm{C}\end{array}$ \\
\hline $\begin{array}{l}\text { Temp between 5- } \\
15 \text { C }\end{array}$ & $\begin{array}{l}\text { Ambient temperature } \\
\text { between } 5-15^{\circ} \mathrm{C}\end{array}$ \\
\hline $\begin{array}{l}\text { Temp greater } \\
\text { than } 25 \mathrm{C}\end{array}$ & $\begin{array}{l}\text { Ambient temperature } \\
\text { greater than } 25^{\circ} \mathrm{C}\end{array}$ \\
\hline Icing conditions & $\begin{array}{l}\text { Presence of ice on the } \\
\text { runway }\end{array}$ \\
\hline Rain & Presence of rains \\
\hline Snow & $\begin{array}{l}\text { Presence of snow on the } \\
\text { runway }\end{array}$ \\
\hline $\begin{array}{l}\text { Frozen } \\
\text { Precipitation }\end{array}$ & Presence of frozen \\
\hline Gusts & Presence of gust \\
\hline Fog & Presence of fog \\
\hline Turboprop & Propeller engine aircraft \\
\hline Foreign OD & $\begin{array}{l}\text { An airport where } \\
\text { international flight } \\
\text { operations take place }\end{array}$ \\
\hline Electric storm & $\begin{array}{l}\text { Presence of electric } \\
\text { storms }\end{array}$ \\
\hline Hub & $\begin{array}{l}\text { An airport where } \\
\text { connecting flight } \\
\text { operations take place }\end{array}$ \\
\hline Night & Land at night time \\
\hline $\begin{array}{l}\text { Log criticality } \\
\text { factor }\end{array}$ & Defined in Equation 4 \\
\hline
\end{tabular}

The risk models are considered, aircraft design and operational, weather related independent variables are used as input parameters. The runway criticality factor, which is an airport runway related input parameter determined by the aircraft type, is the only input parameter account runway dimensions in the excursion probability estimation (Equation 4).

Criticality factor $=L_{R} / L a$

where,

$$
\begin{aligned}
& L_{R} \text { - Runway length required } \\
& L a-\text { Runway length available }
\end{aligned}
$$


This required length depends on factors such as airport elevation, ambient temperature, headwind, tailwind and runway surface condition (wet, snow, ice).

\subsection{Location Model (P2)}

Aircraft final wreckage locations are important findings with regard to associated consequences. Using historical accident data [2, 9], distinct ACRP studies for different event types (landing overruns and veer-offs). These models find the respective probability values that the aircraft passes certain distance from the runway end/edge in case of an overrun/a veeroff respectively (Figure 1).

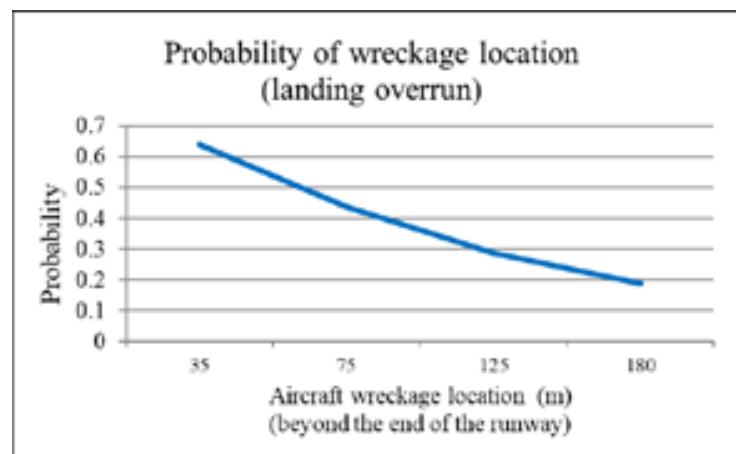

\section{Figure 1 - Aircraft Wreckage Location Probability Curve}

By multiplying event probability with the corresponding location probability, it can estimate the probability that an aircraft stops at a certain distance (a defined distance) from the runway (either longitudinally or laterally) in case of an excursion event.

Considering several location models, this paper uses the models developed by Shirazi et al. [11] for landing overrun location probability estimation (Equation 5) and model developed by Ayres et al. [4] for landing veer-off location probability estimation (Equation 6).

The probability that the overrun aircraft exceeding a given distance $x$ from the runway end is estimated by

$P($ location $>x)=e^{-0.00321 x^{0.9949}}$

where, $x$ is the chosen longitudinal distance from the runway end.

The probability that the veer-off aircraft exceeding a given distance $y$ from the runway centerline is estimated,

$P($ location $>y)=e^{-0.02568 y^{0.904}}$ where, $y$ is a chosen lateral distance from runway the centerline.

\subsection{Consequences}

Accident severity is assessed in terms of the accident consequences. Aircraft wreckage location is also a key determinant factor on respective consequences. All wreckage locations away from the runway end/edge may possess higher kinetic energy. Such higher kinetic energy lends to severe consequences in case of any collision with an obstacle in the adjacent airfield. Based on the damages to human health and aircraft condition, International Civil Aviation Association (ICAO) classifies accident consequences [13]. Moretti et al. (2017) introduced a severity index based on the consequences not only on human health and aircraft but also on the soil bearing capacity of the adjacent safety areas [12].

Considering potential consequences on the aircraft mechanical components at different airfield areas adjacent to runways, this paper defined location based severity levels as in Table 3 and Table 4.

Table 3 - Landing Overrun Severity Classification

\begin{tabular}{|c|c|c|}
\hline $\begin{array}{c}\text { Longitudinal } \\
\text { distance }\end{array}$ & Consequence & Severity \\
\hline$X 1 \mathrm{~m}$ & Major & 0.25 \\
\hline$X 1-X 2 \mathrm{~m}$ & Hazardous & 0.50 \\
\hline$X 2-X 3 \mathrm{~m}$ & Catastrophic & 1.00 \\
\hline
\end{tabular}

Table 4 - Landing Veer-off Severity Classification

\begin{tabular}{|c|c|c|}
\hline $\begin{array}{c}\text { Transverse } \\
\text { distance }\end{array}$ & Consequence & Severity \\
\hline$\Upsilon 1 \mathrm{~m}$ & Major & 0.25 \\
\hline$\Upsilon 1-\Upsilon 2 \mathrm{~m}$ & Hazardous & 0.50 \\
\hline$\Upsilon 2-\Upsilon 3 \mathrm{~m}$ & Catastrophic & 1.00 \\
\hline
\end{tabular}

The excursion risk analysis methodology developed under ACRP studies is adapted for estimating runway excursion risk at the BIA.

\section{Methodology}

\subsection{Excursion Risk Estimation}

The paper analyses various operating conditions that can be experienced at the BIA. The finding to be reasonable for the type of aircraft operating on the BIA. Accordingly, the 
critical aircraft for the BIA runway facility is used for this analysis.

I. Using Equation (4), runway criticality factor is estimated. For the critical aircraft, Airport Planning manual is used to find the required landing length $\left(L_{R}\right)$ at the relevant ambient temperature and runway elevation. Runway length is used as the available runway length $(L a)$.

II. Considering weather data and aircraft operational conditions, input data is inserted into Equation (3).

III. Using Equation (3), event probability (overrun/veer-off probability) is estimated.

IV. As aircraft excursion events may result in distinct consequences, type of event is defined based on the consequences. Accordingly, aircraft risk on the focused event type is estimated.

V. Considering aircraft locations that lead to major events, respective longitudinal distance from the runway end for overrun events, and respective lateral distance from the runway edge are identified. Aircraft wreckage locations beyond the runway safety area are categorized as major events. Hence longitudinal distance $X=240 \mathrm{~m}$ and lateral distance $Y=75 \mathrm{~m}$ are considered for location probability estimations with regard to major events [14].

VI. Using Equations (5) \& (6), respective location probabilities leading to major events are estimated in case of overruns and veer-offs.

VII. The results from step III (event probability) and VI (location probability) are substituted into the Equation (2) for estimating the likelihood of the focused event type (e.g. major event).

VIII. As major events are concerned, the corresponding severity value is inserted into Equation (1). Accordingly, landing overrun risk for major events and landing veer-off risk on major events are estimated.

\subsection{Case Study}

As this paper considers Bandaranaike International Airport (BIA), the corresponding operational and design data are required to be used as model inputs. BIA runway $(04 / 22)$ length $(3350 \mathrm{~m})$ and runway safety area dimensions mentioned in Tables 3, 4 are important airfield design factors. Further, BIA can be considered as a hub airport as connecting flight operations take place with various worldwide destinations. As B747-400 is the critical aircraft for BIA, this paper use B747400 for the analysis [15].

In addition to airport and aircraft related data, weather data plays a vital role in the probability estimation. Using 10-year weather data [16], extreme weather conditions were chosen with regard to tailwind, visibility, runway surface condition and rain. Average ambient temperature $30^{\circ} \mathrm{C}$ is used for the entire analysis. For BIA, none of the rain, tailwind and crosswind conditions at $30^{\circ} \mathrm{C}$ ambient temperature in day time is considered as the base condition. Such a base condition is defined to compare risk at various weather conditions using a common platform. Table 5 defines a set of operational scenarios using potential weather conditions at the BIA. Aircraft overrun and veer-off risk at these scenarios are compared by using the methodology practiced in this paper.

Table 5 - Weather Condition Based Scenario

\begin{tabular}{|c|l|}
\hline Scenario & \multicolumn{1}{|c|}{ Weather Condition } \\
\hline A & Day Time, $30^{\circ} \mathrm{C}$ \\
\hline B & Tailwind 6 knots, $30^{\circ} \mathrm{C}$ \\
\hline C & Tailwind 12 knots, $30^{\circ} \mathrm{C}$ \\
\hline D & Rain, $30^{\circ} \mathrm{C}$ \\
\hline E & Visibility $<4 \mathrm{SM}, 30^{\circ} \mathrm{C}$ \\
\hline F & Visibility $<4 \mathrm{SM}$, rain, $30^{\circ} \mathrm{C}$ \\
\hline G & $\begin{array}{l}\text { Visibility }<4 \mathrm{SM}, 6 \text { knots } \\
\text { tailwind, rain, } 30^{\circ} \mathrm{C}\end{array}$ \\
\hline H & $\begin{array}{l}\text { Visibility }<4 \mathrm{SM}, 12 \text { knots } \\
\text { tailwind, rain, } 30^{\circ} \mathrm{C}\end{array}$ \\
\hline
\end{tabular}




\section{Results}

Considering the above defined extreme operational conditions such as the scenarios $\mathrm{B}$ to $\mathrm{H}$, landing overrun risk on major events (aircraft stops within the runway safety area) at BIA for the critical aircraft B747-400 is estimated. Accordingly, Table 6 shows the respective overrun risks and the worst risk could be observed in condition $\mathrm{H}$ (presence of $12 \mathrm{knot}(6.17 \mathrm{~m} / \mathrm{s})$ tailwind, visibility below 4 SM (6437 meters)). This is about 670 times increase of overrun risk compared to the base condition scenario A.

Table 6 - Landing overrun risk

\begin{tabular}{|c|c|}
\hline Scenario & Landing overrun risk \\
\hline A & $4.96 \mathrm{E}-07$ \\
\hline B & $1.31 \mathrm{E}-06$ \\
\hline C & $1.36 \mathrm{E}-05$ \\
\hline D & $2.47 \mathrm{E}-06$ \\
\hline E & $2.44 \mathrm{E}-06$ \\
\hline F & $1.22 \mathrm{E}-05$ \\
\hline G & $3.29 \mathrm{E}-05$ \\
\hline H & $3.37 \mathrm{E}-04$ \\
\hline
\end{tabular}

Similarly, the estimated veer-off risk of B747400 when it lands on the runway $(04 / 22)$ when the presence of crosswind above 12 knots (6.17 $\mathrm{m} / \mathrm{s})$ is $1.5 \times 10^{-6}$. This is 60 times higher compared to the non-crosswind condition at BIA. Thus, crosswind is a leading risk factor for landing veer-offs. The corresponding impact of the factors such as visibility, rain and tailwind causes to increase successive landing overrun risk at BIA. The analysis highlights that the tailwinds above 12 knots $(6.17 \mathrm{~m} / \mathrm{s})$ when rain at reduced visibility levels are the worst weather conditions for BIA landing operations. The worst overrun risk at the scenario $\mathrm{H}$ is used for further analysis. Considering runway design elements and their improvements, increasing risk could be managed. According to the Equation (4), runway length improvement causes to decrease the overrun risk in terms of runway criticality factors. As shown in Figure 2, 30 percent runway length drops overrun risk by 50 percent. Similarly, as shown in Figure 3, increasing runway safety area will drop overrun risk. This happens by altering possible severe consequences into minor consequences and thus severity values becoming smaller.

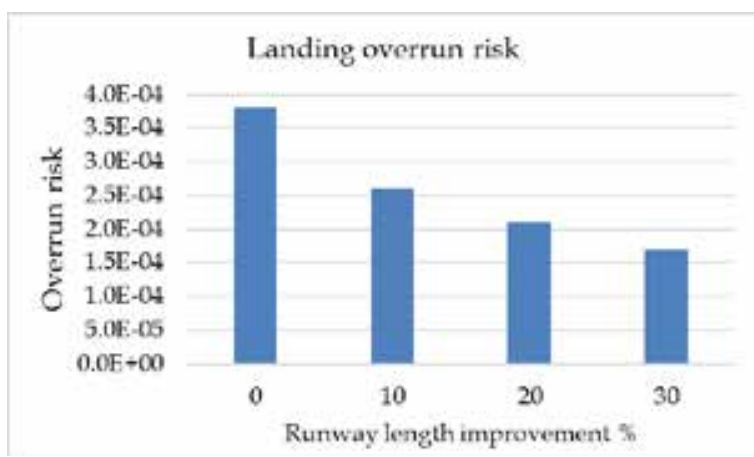

Figure 2 - Landing Overrun Risk with Runway Length Improvement

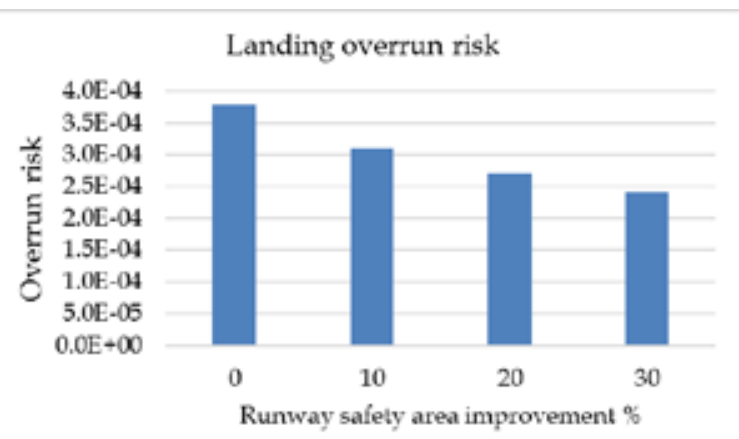

Figure 3 - Landing Overrun Risk with Runway Safety Area Improvement

As Figures 2 and 3 depict, airport airside design elements can manage excursion risks by reducing the event probabilities or minimizing potential event consequences.

\section{Conclusion}

The paper focused on aircraft excursion risk at the Bandaranaike International airport. Considering usual weather pattern at BIA and the probable extreme weather conditions at BIA, aircraft risk on overruns and veer-offs were estimated. Using previous accident data, several probability models and location models have been developed by various aviation professionals and they are being used by the aviation industry for assessing existing facilities and design level applications. The paper used an existing probability model and a location model while developing a severity index. Considering the results, it could be found that the impact of the visibility, rain and tailwind to be high on landing overrun risk. Presence of tailwinds above 12 knots $(6.17 \mathrm{~m} / \mathrm{s})$, rain and reduced visibility levels is the worst weather condition out of the defined weather scenarios. Similarly, crosswinds above 12 knots $(6.17 \mathrm{~m} / \mathrm{s})$ is a critical weather condition on landing veeroffs. Among the runway design element alternations, runway length improvement can significantly reduce landing overrun risk. According to the findings, at the given 
condition, 30 percent runway length improvement reduces over risk by 50 percent. Further, runway safety area improvement minimizes accident consequences, and finally reduce excursion risks.

This mathematical approach on landing overrun and veer-off risk at BIA found that the aircraft operational and weather factors create excursion risk on landing aircraft. Airfield design elements such as runway length, width and safety areas play a vital role for maintaining excursion risks within the acceptable risk levels. Thus, airfield design elements need to be upgraded in terms of potential operational and weather conditions. These operational conditions include new larger aircraft or new fleet types other than the critical aircraft etc. as well. Airfield design elements should have necessary tolerance to bear associated spikes of the aircraft risk due to various unavoidable operational conditions.

\section{Acknowledgement}

We are highly thankful to the academic staff of the Department of Civil Engineering, University of Moratuwa, Sri Lanka who supported us immensely in numerous ways during this research. Moreover, authors wish to acknowledge the assistance given by IESL in preparation of this guide.

\section{References}

1. International Air Transport Association,

Economic Performance of the Airline Industry, 2020.

https://www.iata.org/en/iata-

repository/publications/economic-

reports/airline-industry-economic-performance--june-2020---data-tables, [Visited, 2020/12/06].

2. Hall, J., Ayres, M., Wong, D., Appleyard, A., Eddowes, M., Shirazi, H. et al., Analysis of Aircraft Overruns and Undershoots for Runway Safety Areas, Airport Cooperative Research Program Report 3, Washington, D.C. (USA), 2008.

https://www.icao.int/SAM/Documents/2011/ AGAASEROSTUDIES/ACRP_rpt_003.pdf, [Visited, 2020/12/08].

3. Van Es, G. W. H., Tritscheler, K., Tauss, M., (2009) Development of a landing Overrun Risk Index, NLR Report-TP-2009-280, Air Transport Safety Institute, Netherlands, 2009.

4. Ayres, M., Carvalho, R., Shirazi, H., David, R.E., Development of a Runway Veer-off Location Distribution Risk Assessment Model and Reporting Template, Airport Cooperative Research Program
Report 107, Washington, D.C. (USA), 2014. https://www.nap.edu/download/22411, [Visited, 2020/11/07].

5. International Air Transport Association, Annual Review, 2020.

https://www.iata.org/en/publications/annualreview/ [Visited, 2020/11/29].

6. Wikipedia, Bandaranaike International Airport, 2020.

https://en.wikipedia.org/wiki/Bandaranaike_I nternational_Airport, [Visited, 2020/11/29].

7. Civil Aviation Authority of Sri Lanka, Aircraft Accidents and Incidents, 2020.

https://www.caa.lk/en/aircraft-accident-andincidents, [Visited, 2020/12/01].

8. Wong, KY., The Modelling of Accident Frequency Using Risk Exposure Data for the Assessment of Airport Safety Areas, Loughborough University, England, 2007.

https://core.ac.uk/download/pdf/288389973.p df, [Visited,, 2020/12/06].

9. Ayres, M., Shirazi, H., Carvalho, R., Hall, J., Speir, R., Arambula, E. et al., Improved Models for Risk Assessment of Runway Safety Areas, Airport Cooperative Research Program Report 50, Washington D.C. (USA)., 2011. https://www.nap.edu/download/13635, [Visited, 2020/11/26].

10. Trucco, P., Ambroggi, M., Leva, M. C., Topological risk mapping of runway overrun: $A$ probabilistic approach, Journal of Reliability Engineering and System Safety, 2013. doi: 10.1016/j.ress.2015.06.006

11. Shirazi, H., Hall, J., Williams, B., Moser, S., Boswel, D., Hardy, M. et al., Runway Protection Zones(RPZ) Risk Assessment Tool Users' Guide, Airport Cooperative Research Program Report 168, Washington, D.C. (USA), 2016. https://www.nap.edu/download/24662, [Visited, 2020/11/30].

12. Moretti, L., Cantisani, G., Caro, S., Airport Veeroff Risk Assessment: An Italian Case Study, Journal of Engineering and Applied Sciences, 2017, 12(3), pp. 900-912.

13. International Civil Aviation Organization, Safety Management Manual (SMM), 2012. https://www.icao.int/sam/documents/rstsmsssp-13/smm_3rd_ed_advance.pdf, [Visited, 2020/12/03].

14. Federal Aviation Administration, Advisory Circular for Airport Design (AC 150/5300-13A), 2014.

15. Boeing Airplanes, Airplane Characteristics for Airport Planning, 2012. 
https://www.boeing.com/resources/boeingdot com/commercial/airports/acaps/747_4.pdf,

[Visited, 2020/11/30].

16. Department of Metrology Sri Lanka, Metrological data and information online.

https://www.meteo.gov.lk/index.php?option= com_content\&view $=$ article\&id=195\&Itemid $=565$ \&lang $=$ en, [Visited, 2020/11/29]. 